\title{
'Isabel’ Grape Treated with Abscisic Acid in Different Maturation Stages
}

\author{
Lilian Yukari Yamamoto ${ }^{1}$, Renata Koyama ${ }^{1}$, Izadora Rodrigues de Oliveira ${ }^{1}$, Wellington Fernando Silva Borges ${ }^{1}$, \\ Sergio Ruffo Roberto ${ }^{1 *}$ and Adriane Marinho de Assis $^{2}$ \\ ${ }^{1}$ Department of Agronomy, State Universityof Londrina, Brazil \\ ${ }^{2}$ Departament of Fitotecnia, Federal Universityof Pelotas, Brazil \\ Submission: January 30, 2018.; Published: March 07, 2018 \\ "Corresponding author: Sergio Ruffo Roberto, Department of Agronomy, State University of Londrina, Brazil, Tel: +55(43)3371-4774; \\ Email: sroberto@uel.br
}

\begin{abstract}
Isabel grape is one of the main cultivars used for juice processing, but presents deficiency in anthocyanins, pigments responsible for the color. Thus, an alternative for increasing the color is to promote synthesis of this compound, which can be accomplished using growth regulators, like abscisic acid (ABA). This work aimed to evaluate anthocyanins and polyphenols concentration in berry and juice of 'Isabel' grape treated with abscisic acid in different maturation stages. Statistical model used was a randomized block design with seven treatments and five replications: control; S-ABA 400 $\mathrm{mgL}^{-1}$, applied 7 days before véraison (DBV); $S$-ABA $400 \mathrm{mgL}^{-1}$, applied at véraison (V); 7 days after véraison (DAV); $S$-ABA $400 \mathrm{mgL}^{-1}$, applied 7DBV $+S$-ABA $400 \mathrm{mgL}^{-1} 35$ days after the first application (DAFA); S-ABA 400 $\mathrm{mgL}^{-1}$, applied at V + S-ABA 400 $\mathrm{mgL}^{-1} 35 \mathrm{DAFA}$; and $S$-ABA $400 \mathrm{mgL}^{-1}, 7 \mathrm{DAV}+S$-ABA $400 \mathrm{mgL}^{-1}$ 35DAFA. $S$-ABA application increases anthocyanins concentration, color variables, and acceptability of juices in sensory analysis, without affecting polyphenols concentration. Two applications of $S$-ABA $400 \mathrm{mgL}^{-1}$ provide best results regarding the increment of berries and juice color of 'Isabel' grape.
\end{abstract}

Keywords: Color; Phenolic compound; Plant growth regulator; Sensory analysis; Vitis labrusca

Abbreviations: DBV: Days Before Véraison; V: At Véraison; DAV: Days after Véraison; DAFA: Days after the First Application; CI: Color Intensity; T: Tint; ABA: Abscisic Acid

\section{Introduction}

'Isabel' (Vitis labrusca $L$ ) is one of the main grape cultivars for processing, due to its vigor, tolerance to the main fungal diseases, high yield and potential for sugar accumulation, ranging from 15 to $19^{\circ}$ Brix. However, due to its deficiency in color, 'Isabel' grape juice must be blended with juice from pigment-producing cultivars to obtain products with higher color intensity, but usually, these cultivars are generally unproductive [1].

Anthocyanins are phenolic compounds responsible for the most of red, pink, purple and blue colors observed in the fruits and vegetables [2]. Analysis of gene expression of anthocyanin biosynthetic pathway performed with cells in vitro and grape berries treated with exogenous abscisic acid (ABA) proved the involvement of this plant growth regulator in the biosynthesis of anthocyanins [2-5].

Increase in anthocyanins of grapes by exogenous application of ABA during the onset of ripening (véraison), and the frequency of applications can also influence the results according to the cultivar [5-12]. In 'Isabel' grapes, it was determined that one or two applications of $400 \mathrm{mgL}^{-1}$ of the isomer (S)-cis-abscisic acid (S-ABA) increment the concentration of anthocyanin [13], however, it has not been elucidated about the best time of application of this plant growth regulator, which may vary according to cultivar $[10,14,15]$.

Thus, it is extremely important to determine the ripening stage for application of ABA that most favors the accumulation of anthocyanins in 'Isabel' grape, in order to plan better the application of this plant growth regulator, since in large area or depending on the climate conditions, it is not always possible to apply it at véraison, period characterized by sugar accumulation, softening of berries, synthesis of anthocyanins, among other factors [16].

Thereby, the aim of this study was to evaluate the accumulation of anthocyanins and polyphenols in berries and juice of 'Isabel' grape treated with S-ABA at different stages of ripening.

\section{Materials and Methods}

The study was conducted in a 11-year-old commercial vineyard of own-rooted 'Isabel' grapes (Vitis labrusca) belonging 
to Intervin Winery, located in Maringá, state of Paraná, Brazil $\left(23^{\circ} 25^{\prime} \mathrm{S}, 5^{\circ} 57^{\prime} \mathrm{W}\right.$, altitude $\left.542 \mathrm{~m}\right)$. According to the Köppen classification, the region climate is type $\mathrm{Cfa}$, i.e., subtropical climate with an average temperature in the coldest month below $18{ }^{\circ} \mathrm{C}$ and average temperature in the warmest month above 22 ${ }^{\circ} \mathrm{C}$. The average annual rainfall is of $1,596 \mathrm{~mm}$, with a tendency of concentrated rainfall in the summer months.

The vines were trained on overhead trellises and spaced 4.0 $\mathrm{x} 1.0 \mathrm{~m}$ apart. Pruning was performed to leave 2-3 buds per spur, and subsequently, $5 \%$ hydrogen cyanamide was applied to the buds to induce and standardize sprouting. During the trials, the standard regional cultivation practices with regard to nutrition, weed control and pest and disease management were used.

It was evaluated the effect of $S$-ABA applied to grapes at different stages of ripening, during two consecutive crop years (regular season 2012 and out of season 2013). S-ABA, at an active concentration of $100 \mathrm{gL}^{-1}$, was supplied by Valent Bio Sciences Corporation (Libertyville, IL).

The following treatments were tested: Control (C), in which no S-ABA was applied; $S$-ABA $400 \mathrm{mgL}^{-1}$ applied 7 days before véraison (DBV); $S$-ABA $400 \mathrm{mgL}^{-1}$ applied at véraison (V); $S$-ABA $400 \mathrm{mgL}^{-1}$ applied 7 days after véraison (DAV); $S$-ABA $400 \mathrm{mgL}^{-1}$ applied $7 \mathrm{DBV}+S$-ABA $400 \mathrm{mgL}^{-1}$ at 35 days after first application (DAFA); $S$-ABA $400 \mathrm{mgL}^{-1}$ applied at V $+S$-ABA $400 \mathrm{mgL}^{-1}$ at 35DAFA and; ${ }^{\text {s}}$-ABA $400 \mathrm{mgL}^{-1}$ applied 7DAV $+S$-ABA $400 \mathrm{mgL}^{-1}$ at 35DAFA.

Experimental design applied was randomized blocks with seven treatments and five replicates, with five vines per plot. Fifteen representative clusters in each plot were marked before the application of treatments for further evaluation.

For treatment applications, the solution was prepared using $4 \mathrm{~mL} \mathrm{~L}^{-1}$ of commercial product, which represents a concentration of $400 \mathrm{mgL}^{-1}$ the active ingredient $S$-ABA, and $0.3 \mathrm{~mL} \mathrm{~L}^{-1}$ of Break Thru (Evonik Industries, Germany) non-ionic surfactant for all treatments. Clusters were sprayed in the morning using a knapsack sprayer at a pressure of 568.93 psi (39.22 bars) with JA1 hollow cone nozzle tips at a volume of $800 \mathrm{~L}$ ha- 1 to provide complete and uniform coverage.

In both crop seasons, clusters of each plot were manually harvested when soluble solids reached around $16^{\circ}$ Brix. For each plot, 90 berries were collected for physicochemical analysis with two berries taken from the upper, middle, and bottom regions of each marked cluster.

The physical characteristics of grapes were evaluated by determining the mass $(\mathrm{g})$ and diameter $(\mathrm{mm})$ of berries and the weigh $(\mathrm{g})$ and length $(\mathrm{cm})$ of clusters using a scale and a digital caliper.

Berry color was analyzed using a colorimeter Minolta CR-10 to obtain the following variables from the equatorial portion of berries ( $\mathrm{n}=2$ per berry): $L^{*}$ (lightness), $C^{*}$ (chroma), and $h^{\circ}$ (hue)
(17). Lightness values may range from 0 (black) to 100 (white). Chroma indicates the purity or intensity of color, the distance from gray (achromatic) toward a pure chromatic color, and is calculated from the $\mathrm{a}^{*}$ and $\mathrm{b}^{*}$ values of the CIELab scale system, starts from zero for a completely neutral color, and does not have an arbitrary end, but intensity increases with magnitude. Hue refers to the color wheel and is measured in angles; green, yellow, and red correspond to $180^{\circ}, 90^{\circ}, 0^{\circ}$, respectively [15,18,19].

Whole grape juices from treatment plots were produced by the Welch process (not from concentrate grape juice - NFC), which consists of extracting the juice by steam entrainment using a stainless steel extraction pot with a $7 \mathrm{~kg}$ capacity (Hauber Macanuda, PSM-07 CF) without any added enzyme [13]. For this extraction, a sample of $4 \mathrm{~kg}$ of clusters from each plot was used, producing an average of $2 \mathrm{~L}$ of whole juice. At first, the bottom section of the steamer juicer pot was filled with water and the heat was turned on high. Washed grape samples $(4 \mathrm{~kg})$ were placed in the top section of the steamer and the basket was filled all the way to the top, and the lid was put on. After $45 \mathrm{~min}$, all grape juice was drained into the middle section of the steamer and then bottled at warm temperature $\left(75^{\circ} \mathrm{C}\right)$ into $1 \mathrm{~L}$ capacity sterilized polyethylene containers with lids. After cooling, juice bottles were stored in the refrigerator at $4{ }^{\circ} \mathrm{C}$ for further anthocyanin and polyphenol analyses.

The concentrations of total anthocyanins of berries and juices of all treatments were carried out. For total anthocyanin extraction 30 berries were homogenized in a blender and $50 \mathrm{~g}$ of this mixture or $50 \mathrm{~mL}$ of juice were used to quantification. Samples were macerated and homogenized with $150 \mathrm{~mL}$ of extracting solution $(70 \mathrm{~mL}$ of ethanol $70 \%$ and $30 \mathrm{~mL}$ of $\mathrm{HCl} 0.1 \%$, $\mathrm{pH} 2.0$ ) for $2 \mathrm{~min}$ in a blender, then placed in a beaker covered with parafilm and aluminum foil, and extracted in darkness for $12 \mathrm{~h}$ at $4{ }^{\circ} \mathrm{C}$. Afterward, a filtration was made, and then $100 \mathrm{~mL}$ of this solution were mixed with $100 \mathrm{~mL}$ of extracting solution. An aliquot of $2.0 \mathrm{~mL}$ was taken from the stock solution and completed to $100 \mathrm{~mL}$ with the extracting solution and leaving it at room temperature in darkness for $2 \mathrm{~h}$, the extracting solution was used as a blank. The absorbance of each sample from berries and juices was determined at $535 \mathrm{~nm}$ using a spectrophotometer (Thermo Scientific; Genesys TM, 10S ultraviolet-Vis). Readings were expressed as milligrams of total anthocyanins as malvidin3 -glucoside per $100 \mathrm{~g}$ of berries (mg $100 \mathrm{~g}^{-1}$ ) and per liter of juice $\left(\mathrm{mg} \mathrm{L}^{-1}\right)[20]$.

In order to obtain total anthocyanin daily accumulation rate in berries (mg $100 \mathrm{~g}^{-1}$ day $^{-1}$ ), grapes of all treatments were sampled weekly from the first application of $S$-ABA to harvest, in a total of six samplings, using best fit model equation of the first degree regression.

The concentrations of total polyphenols of berries and juices were determined by spectro photometric Folin-Ciocalteau method [21]. For total polyphenol extraction from berries, samples of 30 berries per plot were macerated and then $5 \mathrm{~g}$ were 
homogenized with $50 \mathrm{~mL}$ of ethanol $50 \%$ in a blender during $2 \mathrm{~min}$ and centrifuged at $3500 \mathrm{rpm}$ during $5 \mathrm{~min}$. An aliquot of $0.2 \mathrm{~mL}$ of the extract was mixed with $1.8 \mathrm{~mL}$ of distilled water and $10 \mathrm{~mL}$ of 10 -fold diluted Folin-Ciocalteau reagent. After $30 \mathrm{~s}$ to $8 \mathrm{~min}, 8 \mathrm{~mL}$ of $7.5 \%$ of $\mathrm{Na}_{2} \mathrm{CO}_{3}$ solution was added. All test tubes with the mixture were shaken for 10 s on the vortex and kept in darkness during $2 \mathrm{~h}$. For total polyphenol extraction from grape juices, samples of $5 \mathrm{~mL}$ of whole juice per plot were used. Absorbance of each sample from berries and juices was measured after $15 \mathrm{~min}$ at $765 \mathrm{~nm}$ using a spectrophotometer (Thermo Scientific; Genesys, 10S ultraviolet-Vis) against a blank sample. The blank sample was prepared with water instead of the extract. Determination of total polyphenol was calculated from the calibration curve obtained with gallic acid. Readings were expressed as mg $100 \mathrm{~g}^{-1}$ of berries and $\mathrm{gL}^{-1}$ of juice (Gallic acid equivalents).

Juice color was assessed through the direct measurement of the optical density of the samples, without dilution, using a spectrophotometer UV-V is with a $1.0 \mathrm{~mm}$ path-length cuvette to obtain the optical density at $420 \mathrm{~nm}$ (yellow), 520nm (red) and $620 \mathrm{~nm}$ (violet). Color intensity (CI) was determined by summing the optical density of each sample at 420,520 and $620 \mathrm{~nm}$. Tint (T) was obtained by the ratio between the absorbance at $420 \mathrm{~nm}$ and 520nm [22].

Sensory analysis of grape juice was performed adopting a randomized block experimental design, with 70 untrained tasters. Evaluations were performed in individual booths with special daylight lighting in the Sensory Analysis Laboratory. The color, aroma, flavor, body, and consumer acceptance of the juice samples were evaluated using a 9-point hedonic scale, which ranged from "dislike extremely [1]" to "like extremely [9]" [23]. Samples were served at $4{ }^{\circ} \mathrm{C}$ in transparent acrylic glasses at a volume of $40 \mathrm{~mL}$ per sample. Each taster received the seven treatment samples, coded with random three-digit numbers in randomized order. Drinking water at room temperature was served to the panelists for mouth cleaning before and between evaluations of grape juice samples.

Means were subjected to analysis of variance and compared using the Scott-Knott test at 5\% probability. Because results observed for each crop season were quite similar, means of the combined crops were considered for discussion [13].

\section{Results and Discussion}

For grape physical characteristics, such as mass and diameter of the berries and mass and length of clusters, there was no difference in relation to the application of $S$-ABA at different maturation stages of 'Isabel' grape (Table 1). Similarly, the application of ABA did not affect the physical characteristics of different grape cultivar, such as Isabel, Cabernet Sauvignon, Benitaka and Rubi $[7,11,12,24]$. However, in study with 'Flame Seedless' and 'Redglobe' grapes, there was no effect of S-ABA application in the mass of berries in some seasons $[10,15]$. These variations in the results suggest that $S$-ABA does not influence directly in the physical characteristics of the grapes, which are more related to climatic factors of the season.

Table 1: Mass and diameter of berries and mass and length of clusters of 'Isabel' grapes subjected to different treatments of (S)-cis-abscisic acid (S-ABA).

\begin{tabular}{|c|c|c|c|c|}
\hline Treatments $\left(\boldsymbol{S}\right.$-ABA $\mathbf{4 0 0} \mathbf{m g L}^{-1}$ ) & Mass of Berries $\mathbf{( g )}$ & Diam of Berries (mm) & Mass of Clusters (g) & Length of Clusters (cm) \\
\hline Control & $3.6 \mathrm{NS} \pm 0.2$ & $16.4 \mathrm{NS} \pm 0.4$ & $115.9 \mathrm{NS} \pm 2.3$ & $9.3 \mathrm{NS} \pm 0.1$ \\
\hline 7DBV & $3.5 \pm 0.1$ & $16.6 \pm 0.2$ & $110.8 \pm 3.2$ & $9.4 \pm 0.2$ \\
\hline V & $3.5 \pm 0.1$ & $16.6 \pm 0.3$ & $109.5 \pm 2.6$ & $9.2 \pm 0.4$ \\
\hline 7DAV & $3.5 \pm 0.1$ & $16.3 \pm 0.3$ & $123.5 \pm 5.3$ & $9.4 \pm 0.1$ \\
\hline 7DBV + 35DAFA & $3.6 \pm 0.1$ & $16.9 \pm 0.3$ & $117.8 \pm 10.5$ & $9.5 \pm 0.4$ \\
\hline V + 35DAFA & $3.7 \pm 0.1$ & $16.8 \pm 0.2$ & $120.0 \pm 9.2$ & $9.3 \pm 0.2$ \\
\hline 7DAV + 35DAFA & $3.6 \pm 0.1$ & $16.8 \pm 0.2$ & $110.1 \pm 6.0$ & 9.0 \\
\hline
\end{tabular}

OBS: Average of 2012 and 2013 seasons. 7DBV: 7d before véraison; V: at véraison; 7 DAV: 7 d after véraison; 35 DAFA: 35 $\mathrm{d}$ after the first application. Means within columns followed by different letters differ significantly by Scott-Knott's test $(P<0.05)$. NS: non significant.

Regarding to total anthocyanins evaluation, there was an increase of its concentration in S-ABA treated berries, and treatments using two applications (7DBV + 35DAFA, V + 35DAFA e 7DAV + 35DAFA) were more effective than a single application (7DBV, $\mathrm{V}$ e 7DAV), independently to the application period (Table 2). For total anthocyanins of juices, the results were repeated, except for the treatment 7DBV which the single application provided similar accumulation to treatment with two applications, regardless of the maturation phase. This result 
indicates that application of S-ABA near véraison allows the greater anthocyanin accumulation in 'Isabel' grape juice.

OBS: Average of 2012 and 2013 seasons. 7DBV: 7 d before véraison; V: at véraison; 7 DAV: 7 d after véraison; 35 DAFA: 35 $\mathrm{d}$ after the first application. Means within columns followed by different letters differ significantly by Scott-Knott's test $(P<0.05)$. NS: non significant.

These results suggest that the effect of S-ABA application in anthocyanin accumulation of berries is not accurately transferred to the juices. In a study with 'Isabel' grape, also there was not the same increase ratio of the concentration of anthocyanins of berries in juices, in which for berries the application of 200 or $400 \mathrm{mgL}^{-1} \mathrm{~S}$-ABA, independent of the application period, increased the anthocyanin concentration. In contrast, for juice, application of $400 \mathrm{mgL}^{-1}$ of one or two times was more effective [13].

Table 2: Total anthocyanins and polyphenols of berries and whole juice of 'Isabel' grapes subjected to different treatments of ( $S$ )-cis-abscisic acid (S-ABA).

\begin{tabular}{|c|c|c|c|c|}
\hline Treatments (S-ABA $\left.400 \mathrm{mgL}^{-1}\right)$ & $\begin{array}{l}\text { Total Anthocyanin of } \\
\left.\text { Berries (mg 100 } \mathrm{g}^{-1}\right)\end{array}$ & $\begin{array}{l}\text { Total Anthocyanin of } \\
\text { Juice }\left(\mathrm{mgL}^{-1}\right)\end{array}$ & $\begin{array}{l}\text { Total Polyphenols of } \\
\text { Berries (mg 100 } \mathrm{g}^{-1} \text { ) }\end{array}$ & Total Polyphenols of Juice (mg L $\left.\mathrm{L}^{-1}\right)$ \\
\hline Control & $13.4 \pm 1.4 \mathrm{c}$ & $79.0 \pm 14.0 \mathrm{c}$ & $32.8 \mathrm{NS} \pm 2.5$ & $2.3 \mathrm{NS} \pm 0.2$ \\
\hline 7DBV & $17.5 \pm 1.0 \mathrm{~b}$ & $94.4 \pm 7.1 \mathrm{a}$ & $34.2 \pm 3.3$ & $2.3 \pm 0.2$ \\
\hline $\mathrm{V}$ & $17.6 \pm 1.0 \mathrm{~b}$ & $84.7 \pm 5.9 \mathrm{~b}$ & $33.4 \pm 2.6$ & $2.2 \pm 0.2$ \\
\hline 7DAV & $17.9 \pm 1.6 \mathrm{~b}$ & $87.7 \pm 5.9 \mathrm{~b}$ & $38.3 \pm 3.6$ & $2.3 \pm 0.1$ \\
\hline $7 \mathrm{DBV}+35 \mathrm{DAFA}$ & $21.2 \pm 0.2 \mathrm{a}$ & $110.3 \pm 14.6 \mathrm{a}$ & $33.3 \pm 4.8$ & $2.4 \pm 0.2$ \\
\hline$V+35 D A F A$ & $21.6 \pm 1.5 \mathrm{a}$ & $105.7 \pm 11.2 \mathrm{a}$ & $36.1 \pm 3.9$ & $2.4 \pm 0.2$ \\
\hline $7 \mathrm{DAV}+35 \mathrm{DAFA}$ & $19.4 \pm 0.7 \mathrm{a}$ & $96.5 \pm 8.8 \mathrm{a}$ & $39.4 \pm 2.3$ & $2.5 \pm 0.2$ \\
\hline
\end{tabular}

Table 3: Total anthocyanin daily accumulation rate in berries of 'Isabel' grape subjected to different treatments of (S)-cis-abscisic acid (S-ABA) (anthocyanin $=\mathrm{A}+\mathrm{B}$. Time day $\left.^{-1}\right)$.

\begin{tabular}{|c|c|c|c|}
\hline Treatment (S-ABA 400 $\mathbf{m ~ L ~ L}^{-1}$ ) & A anthocyanin & B Anthocyanin Accumulation Rate $\left(\mathbf{m g ~ 1 0 0 g}^{\mathbf{1}} \mathbf{D a y}^{\mathbf{1}}\right)$ & $\mathbf{R}^{\mathbf{2}}$ / \\
\hline Control & $-60.4 \pm 4.3$ & $0.55 \pm 0.03$ & $0.97^{*}$ \\
\hline 7DBV & $-75.3 \pm 6.7$ & $0.68 \pm 0.05$ & $0.96^{*}$ \\
\hline V & $-61.1 \pm 5.7$ & $0.55 \pm 0.04$ & $0.97^{*}$ \\
\hline 7DAV & $-64.6 \pm 5.4$ & $0.58 \pm 0.04$ & $0.97^{*}$ \\
\hline 7DBV + 35DAFA & $-78.4 \pm 8.7$ & $0.71 \pm 0.07$ & $0.96^{*}$ \\
\hline V + 35DAFA & $-73.6 \pm 6.9$ & $0.66 \pm 0.06$ & $0.95^{*}$ \\
\hline 7DAV + 35DAFA & $-68.9 \pm 5.9$ & $0.63 \pm 0.05$ & $0.97^{*}$ \\
\hline
\end{tabular}

OBS: Average of 2012 and 2013 seasons. 7DBV: $7 \mathrm{~d}$ before véraison; $\mathrm{V}=$ at véraison; 7 DAV: 7 d after véraison; 35 DAFA: 35 $\mathrm{d}$ after the first application. a/: Coefficient determination of the regression analysis. *: Significance $(P<0.05)$.

This reinforces that a single application of this plant growth regulator at $7 \mathrm{DBV}$ is sufficient to increase significantly the anthocyanin accumulation, and that a second application at 35DAFA reinforces daily accumulation rate.

It is noted that the determination of the optimum time of application of ABA on grapes is critical, since green berries (pre-véraison) are the tissues most responsive to treatment,
The increase in anthocyanin concentration with ABA application was also observed in berries, skin, pulp or juice in experiments with 'Cabernet Sauvignon', 'Crimson Seedless', 'Pinot Noir', 'Merlot' and 'Beihong' grapes [5-8,14,24-27]. However, beyond the cultivar, anthocyanin concentration increasing with ABA application is also influenced by climatic conditions, since in some seasons its accumulation may be inexpressive, as verified in 'Redglobe' [10] and 'Crimson Seedless' [28].

Regarding the daily anthocyanin accumulation rate in the period between the application of $S$-ABA to harvest of grapes, it was verified that treatments with two applications of S-ABA (7DBV + 35DAFA, V + 35DAFA e 7DAV + 35DAFA) or an application at $7 \mathrm{DBV}$ presented rates that stand out from the control and the other treatments (Table 3), confirming the results obtained for the concentration of anthocyanins in 'Isabel' grape juice (Table 2). 
and hence color of berries, as verified in 'Benitaka' and 'Rubi' grapes, which presented more intense color when received two applications of $S$-ABA $[11,12]$. Although the authors have not evaluated the anthocyanin concentration in skin, since color is related to the concentration of the same, it appears that they were also higher in these conditions. On the other hand, it was reported that the number of $S$-ABA applications did not influence anthocyanin concentration in 'Redglobe' grape [10]. In this study, two or a single applications of $S$-ABA seven days before véraison were more effective, suggesting that a single application is sufficient to increase the anthocyanin, allowing the economy of plant growth regulator, as well as the use of hand labor and machinery for application.

In relation of total polyphenols, there was no difference between treatments, in both berries and juice of 'Isabel' grape (Table 2). Likewise, it was reported that $S$-ABA application did not alter the total polyphenols from 'Isabel' grape berries; however, it was observed its increase in juice, independent of concentration and time of application [13]. In studies realized with 'Malbec' and 'Cabernet Sauvignon' grapes there was an increase of total polyphenols when treated with ABA [6,29].

Some factors such as processing, cultivar, growing region and cultural practices adopted can influence phenolic compounds concentration in grape. Because it is a combination of several compounds, as flavonoids (flavonols, flavones, flavonols, isoflavones, flavanones and anthocyanidins) and non-flavonoids (phenolic acids, coumarins, stilbenes, tannins and lignans), the results observed regarding to its concentration and anthocyanins do not have the same relationship, as verified among 'Concord' clones and rootstocks regarding the phenolic compounds; however, there was no difference in relation to anthocyanins [31].

Total anthocyanins and polyphenols concentrations also differ between berries and juice, and it was recorded higher concentrations in berries, showing that they are not fully transferred to the juice. This fact can be explained by the heating during juice elaboration, which may cause degradation of these compounds, as well by extraction method, since the alcohol used as solvent in berries extract more phenolic compounds.

For variables related to grape color, there was no difference between treatments for lightness $\left(L^{*}\right)$ and hue $\left(h^{\circ}\right)$ (Table 4$)$. In treatments that received an application of $S$-ABA at 7DBV and $\mathrm{V}$, as well as those which received two applications (7DBV + 35DAFA, $\mathrm{V}+$ 35DAFA e 7DAV + 35DAFA), it was verified the lowest mean of $L^{*}$, indicating color more intense of berries. The $\mathrm{h}^{\circ}$ values are related to higher anthocyanin contents, since the darker grapes have higher anthocyanins concentrations, with the highest average recorded with a single application of $S$-ABA $7 \mathrm{DAV}$ and two applications at $7 \mathrm{DBV}$ and 7 DAV. In experiment conducted with 'Isabel' grape, two applications of $S$-ABA, independent of its concentration were more effective in reducing $L^{*}$, and for $C^{*}$ there was a reduction with application of growth regulators in all treatments, with no difference for $h^{\circ}$ [13]. S-ABA application also intensified the color of 'Benitaka' [11] and 'Rubi' grapes [12], which showed lower average $L^{*}$ when received two applications of plant growth regulator.

Regarding the application period of $S$-ABA, depending on grape cultivar, there can be no change of berry color variables [10]. On the other hand, there are reports that the best application time for color variables increment of table grapes grown in California, USA, is the véraison [28], or an application of $400 \mathrm{mgL}^{-1} S$-ABA, a week after véraison or two applications, at the first and fourth week after véraison, for grapes grown in region of Puglia, Italy [32].

Results observed regarding anthocyanins concentrations of berries (Table 2) were not similar to berries color variables (Table 4), whereas large differences in skin pigment content may have little effect on berry color, it is important to evaluate the cultural practices effect in berry color through color and anthocyanin concentration in skin together $[15,28]$.

Table 4: Lightness $\left(L^{*}\right)$, chroma $\left(C^{*}\right)$ and hue angle $\left(h^{\circ}\right)$ of 'Isabel' berries subjected to different treatments of $(S)$-cis-absisic acid $(S-A B A)$.

\begin{tabular}{|c|c|c|c|}
\hline Treatments (S-ABA 400 $\mathbf{m g ~ L}^{-1}$ ) & $\mathbf{L}^{*}$ & C $^{*}$ & h $^{\circ}$ \\
\hline Control & $25.3 \pm 0.3 \mathrm{a}$ & $2.1 \mathrm{NS} \pm 0.2$ & $150.4 \pm 5.3 \mathrm{~b}$ \\
\hline 7DBV & $23.9 \pm 0.5 \mathrm{~b}$ & $2.3 \pm 0.1$ & $152.9 \pm 2.5 \mathrm{~b}$ \\
\hline V & $24.4 \pm 0.4 \mathrm{~b}$ & $2.3 \pm 0.3$ & $150.2 \pm 5.2 \mathrm{~b}$ \\
\hline 7DAV & $24.7 \pm 0.3 \mathrm{a}$ & $2.2 \pm 0.1$ & $159.6 \pm 4.4 \mathrm{a}$ \\
\hline 7DBV + 35DAFA & $23.7 \pm 0.5 \mathrm{~b}$ & $2.4 \pm 0.1$ & $158.9 \pm 5.3 \mathrm{a}$ \\
\hline V + 35DAFA & $24.1 \pm 0.3 \mathrm{~b}$ & $2.6 \pm 0.1$ & $154.4 \pm 1.8 \mathrm{~b}$ \\
\hline 7DAV + 35DAFA & $23.9 \pm 0.5 \mathrm{~b}$ & $2.3 \pm 0.1$ & $164.1 \pm 3.7 \mathrm{a}$ \\
\hline
\end{tabular}

OBS: Average of 2012 and 2013 seasons. $L^{*}=$ lightness; $C^{*}$ = chroma; $h^{o}=$ hue angle; $7 \mathrm{DBV}=7 \mathrm{~d}$ before véraison; $\mathrm{V}=$ at véraison; $7 \mathrm{DAV}=7 \mathrm{~d}$ after véraison; $35 \mathrm{DAFA}=35 \mathrm{~d}$ after the first application. Means within columns followed by different letters differ significantly by Scott-Knott's test $(P<0.05)$. NS $=$ non significant.
Concerning juice color obtained by the optical densities, there were differences for all variables, except for tint, which had no influence of $S$-ABA application (Table 5). For 420 and $520 \mathrm{~nm}$ optical densities and color intensity, treatments with two application of $S$-ABA (7DBV + 35DAFA, V + 35DAFA e 7DAV $+35 \mathrm{DAFA}$ ) resulted in highest average, on the other hand, for 
$620 \mathrm{~nm}$ density, only treatment with two applications (7DBV + 35DAFA) had the highest average.

Table 5: Optical density at 420, 520 and $620 \mathrm{~nm}$, color intensity $(\mathrm{Cl})$ and tint $(\mathrm{T})$ of 'Isabel' berries subjected to different treatments of $(S)$-cisabsisic acid (S-ABA).

\begin{tabular}{|c|c|c|c|c|c|}
\hline Treatments $\left(\boldsymbol{S}\right.$-ABA 400 $\left.\mathbf{m ~ L ~ L}^{-\mathbf{1}}\right)$ & $\mathbf{4 2 0}$ & $\mathbf{5 2 0}$ & $\mathbf{6 2 0}$ & CI & T \\
\hline Control & $0.460 \pm 0.05 \mathrm{~b}$ & $0.937 \pm 0.12 \mathrm{~b}$ & $0.178 \pm 0.02 \mathrm{~b}$ & $1.574 \pm 0.20 \mathrm{~b}$ & $0.486 \mathrm{NS} \pm 0.01$ \\
\hline 7DBV & $0.502 \pm 0.05 \mathrm{~b}$ & $1.086 \pm 0.13 \mathrm{~b}$ & $0.196 \pm 0.02 \mathrm{~b}$ & $1.783 \pm 0.19 \mathrm{~b}$ & $0.467 \pm 0.02$ \\
\hline V & $0.469 \pm 0.03 \mathrm{~b}$ & $0.993 \pm 0.09 \mathrm{~b}$ & $0.182 \pm 0.02 \mathrm{~b}$ & $1.644 \pm 0.13 \mathrm{~b}$ & $0.471 \pm 0.01$ \\
\hline 7DAV & $0.495 \pm 0.04 \mathrm{~b}$ & $1.021 \pm 0.08 \mathrm{~b}$ & $0.191 \pm 0.02 \mathrm{~b}$ & $1.707 \pm 0.13 \mathrm{~b}$ & $0.482 \pm 0.01$ \\
\hline 7DBV + 35DAFA & $0.604 \pm 0.08 \mathrm{a}$ & $1.322 \pm 0.20 \mathrm{a}$ & $0.250 \pm 0.02 \mathrm{a}$ & $2.175 \pm 0.32 \mathrm{a}$ & $0.462 \pm 0.01$ \\
\hline V + 35DAFA & $0.534 \pm 0.04 \mathrm{a}$ & $1.156 \pm 0.10 \mathrm{a}$ & $0.210 \pm 0.02 \mathrm{~b}$ & $1.900 \pm 0.16 \mathrm{a}$ & $0.467 \pm 0.02$ \\
\hline 7DAV + 35DAFA & $0.558 \pm 0.05 \mathrm{a}$ & $1.208 \pm 0.15 \mathrm{a}$ & $0.212 \pm 0.02 \mathrm{~b}$ & $1.978 \pm 0.22 \mathrm{a}$ & $0.470 \pm 0.01$ \\
\hline
\end{tabular}

OBS: Average of 2012 and 2013 seasons. 7DBV $=7 \mathrm{~d}$ before véraison; $\mathrm{V}=$ at véraison; $7 \mathrm{DAV}=7 \mathrm{~d}$ after véraison; $35 \mathrm{DAFA}=$ $35 \mathrm{~d}$ after the first application. Means within columns followed by different letters differ significantly by Scott-Knott's test $(P$ $<0.05)$. NS = non significant.

In evaluation of juice color by optical density, the $520 \mathrm{~nm}$ band expresses red color intensity and mainly depends of anthocyanins amount [31]. Two applications of S-ABA, regardless of the time, provide higher menas, confirming the results obtained for anthocyanin concentration in juices treated with growth regulators (Table 2). These averages were lower compared to 'Concord' clones (1.257) [31], showing the lowest anthocyanin concentration in 'Isabel' grape, which is usually blended with color rich grapes, such as 'Concord'. However, it is noteworthy that in 'Isabel' grape juice sensory analysis, juice blended with $20 \%$ of 'Concord' showed the same acceptance

\footnotetext{
(c)
}

of $100 \%$ 'Isabel' grape juice for color attribute, which suggests that the means of juices treated with $S$-ABA can be sufficient for consumer acceptance [33].

Sensory analysis showed that the juice there was difference between treatments for color, flavor and consumer acceptance of juices (Figure 1). Juices made from grapes that received an application $7 \mathrm{DBV}$ or two applications (7DBV + 35DAFA, V + 35DAFA e 7DAV + 35DAFA) of $S$-ABA had the highest scores for color, which are in accordance with the results for anthocyanins concentration in juices (Table 2). Average of 2012 and 2013 seasons. Note: means within bars followed by different letters differ significantly by Scott-Knott's test $(P<0.05)$; NS $=$ non significant. 7DBV = $7 \mathrm{~d}$ before véraison; $\mathrm{V}=$ at véraison; $7 \mathrm{DAV}=7$ $\mathrm{d}$ after véraison; $35 \mathrm{DAFA}=35 \mathrm{~d}$ after the first application; Ninepoint hedonic scale: dislike extremely (1) to like extremely (9).

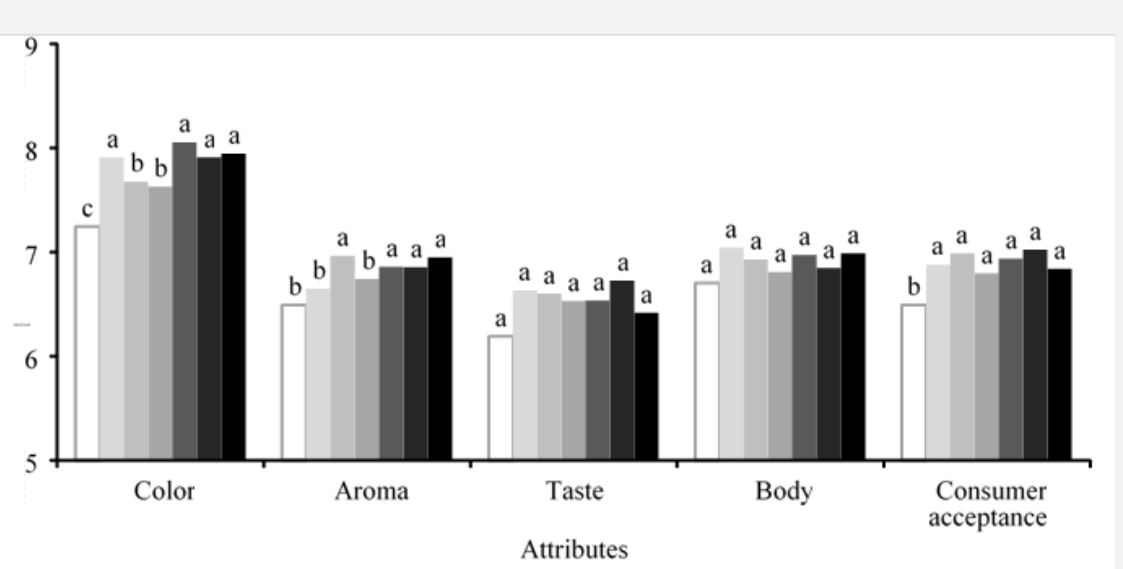

$\square$ Control $=7 \mathrm{DBV}=\mathrm{V}=7 \mathrm{DAV}=7 \mathrm{DBV}+35 \mathrm{DAFA}=\mathrm{V}+35 \mathrm{DAFA} \cdot 7 \mathrm{DAV}+35 \mathrm{DAFA}$

Figure 1: Nine-point hedonic scale for color, aroma, taste, body, and consumer acceptance of 'Isabel' whole juice with grapes subjected to different treatments with $400 \mathrm{mg} \mathrm{L}^{-1}(\mathrm{~S})$-cis-abscisic acid (S-ABA).

For 'Isabel' grape juice, blend with pigmented cultivars, such as BRS Rúbea, BRS Cora, BRS Violet and BRS Carmen, is suggested in order to improve juice color [33]. Thus, the results obtained in this work for anthocyanin concentration and sensory analysis show that the use of this growth regulator can be an alternative to increase color of 'Isabel' grape juice, and can supply the need for blend with other cultivars.

Besides the results on the color acceptability, the application of $S$-ABA also favored aroma and consumer acceptance attributes. For aroma, an application or two applications (7DBV 


\section{JOJ Horticulture \& Arboriculture}

+ 35DAFA, V + 35DAFA e 7DAV + 35DAFA) of S-ABA in grapes presented the highest levels of juices acceptability. For consumer acceptance, the juices that were elaborated with grapes treated with $S$-ABA, regardless of the maturation stage and the number of applications received the highest scores. Likewise, it was reported that juice from 'Isabel' grapes treated with $S$-ABA were more accepted in sensory analysis $[13,34]$.

Thus, one or two applications of $400 \mathrm{mgL}^{-1} S$-ABA before, during or after véraison do not alter the physical characteristics of berries and cluster, as well as the concentration of polyphenols. Moreover, the use of $S$-ABA increases the concentration of total anthocyanins and color, in both berry and juice of 'Isabel' grape. Thereby, considering the most of the characteristics evaluated, two applications (7DBV + 35DAFA, V + 35DAFA e 7DAV + 35DAFA) in 'Isabel' grape can be performed to increase juice color.

\section{Conclusion}

$S$-ABA application increases the concentration of total anthocyanins and color, in berries and juice, as well as the acceptability of juices in sensory analysis, without affecting the concentration of total polyphenols. Two applications of $S$-ABA (7DBV + 35DAFA, $\mathrm{V}+35 \mathrm{DAFA}$ e 7DAV + 35DAFA) 400mgL ${ }^{-1}$ provide the best results in the increase of the color of berries and juices.

\section{Acknowledgement}

The authors are grateful for the financial support provided by CAPES, CNPq and Valent Bio Sciences Corporation for providing $S$-ABA.

\section{References}

1. Camargo UA, Maia JDG, Ritschel PS (2010) Embrapa Uva e Vinho: novas cultivares brasileiras de uva. Bento Gonçalves, Brazil p.64.

2. Taiz L, Zeiger E (2010) Plant Phisiology. Annals of botany 91(6): 782.

3. Ban T, Ishimaru M, Kobayashi S, Shiozaki S, Goto-Yamamoto N (2003) Abscisic acid and 2, 4-dichlorophenoxyacetic acid affect the expression of anthocyanin biosynthetic pathway genes in 'Kyoho' grape berries. Journal of Horticultural Science and Biotechnology 78(3): 586-589.

4. Hiratsuka S, Onodera H, Kawai Y, Kubo T, Itoh H, et al. (2001) ABA and sugar effects on anthocyanin formation in grape berry cultured in vitro. Science of Horticulture 90: 121-130.

5. Owen SJ, Lafond MD, Bowen P, Bogdanoff C, Usher K, et al. (2009) Profiles of abscisic acid and its catabolites in developing Merlot grape (Vitis vinifera) berries. American Journal of Enology and Viticulture 60(3): 277-284

6. Deis L, Canagnaro B, Rubens B, Wuilloud R, Silva MF (2011) Water deficit and exogenous ABA significantly affect grape and wine phenolic composition under in field and in-vitro conditions. Journal of Plant Growth Regulation 65(1): 11-21.

7. Koyama K, Sadamatsu K, Goto-Yamamoto N (2010) Abscisic acid stimulated ripening and gene expression in berry skins of the Cabernet Sauvignon grape. Func Integr Genomics 10(3): 367-381.

8. Mori K, Saito H, Yamamoto-Goto N, Kitayama M, Kobayashi S, et al (2005) Effects of abscisic acid treatment and night temperatures on anthocyanin composition in Pinot noir grapes. Vitis 44(4): 161-165.
9. Peppi MC, Fidelibus MW (2008) Effects of Forchlorfenuron and abscisic acid on the quality of 'Flame Seedless' grapes. Hortscience 43(1): 173176.

10. Peppi MC, Fidelibus MW, Dokoozlian N (2007) Application timing and concentration of abscisic acid affect the quality of 'Redglobe' grapes. Journal of Horticultural Science and Biotechnology 82 (2): 304-310.

11. Roberto SR, Assis AM, Yamamoto LY, Miotto LCV, Sato AJ et al. (2012) Application timing and concentration of abscisic acid improve color of 'Benitaka' table grape. Science Horticulture 142: 44-48.

12. Roberto SR, Assis AM, Yamamoto LY, Miotto LCV, Sato AJ et al. (2013) Ethephon use and application timing of abscisic acid for improving color of 'Rubi' table grape. Pesquisa Agropecuária Brasileira 48 (7): 797-800.

13. Koyama R, Assis AM, Yamamoto LY, Borges FW, Borges RS et al. (2014) Exogenous abscisic acid increases the anthocyanin concentration of berry and juice from 'Isabel' grapes (Vitis labrusca L.). Hortscience, 49(4): 460-464

14. Giribaldi M, Hartung W, Schubert A (2011) The effects of abscisic acid on grape berry ripening are affected by the timing of treatment. Journal International Des Sciences De La Vigne Et Du Vin 44: 9-15.

15. Peppi MC, Fidelibus MW, Dokoozlian N (2006) Abscisic acid application timing and concentration affect firmness, pigmentation and color of 'Flame Seedless' grapes. HortScience 41(6): 1440-1445.

16. Robinson SP, Davies C (2000) Molecular biology of grape berry ripening. Australian Journal of Grape Wine Research 6(2): 175-188.

17. Cantín MC, Fidelibus MW, Crisosto CH (2007) Application of abscisic acid $(A B A)$ at véraison advanced red color development and maintained postharvest quality of 'Crimson Seedless' grapes. Postharvest Biol. Technol 46(3): 237-241.

18. Lancaster JE, Lister CE, Reay PF, Triggs CM (1997) Influence of pigment composition on skin color in a wide range of fruits and vegetables. Journal of the American Society for Horticultural Science 122(4): 594598.

19. Macguire RG (1992) Reporting of objective color measurements HortScience 27(12): 1254-1255.

20. Clemente E, Galli D (2013) Stability evaluation of anthocyanin extracted from processed grape residues. International Journal of Sciences 2: 1218.

21. Bucic-Kojic A, Planinić M, Tomas S, Bilić M, Velić D (2007) Study of solid-liquid extraction kinetics of total polyphenols from grapes seeds. Journal of Food Engineering 81: 236-242.

22. Rizzon LA (2010) Metodologia para análise de vinho. Embrapa Informação Tecnológica, Brazil p. 120.

23. Villanueva NDM, Petenateb AJ, Silva MAAP (2005) Performance of hybrid hedonic scale as compared to the traditional hedonic, selfadjusting and ranking scales. Food Quality and Preference 16(8): 691703.

24. Jeong ST, Goto-Yamamoto N, Kobayashi S, Esaka M (2004) Effects of plant hormones and shading on the accumulation of and the expression of anthocyanin biosynthetic genes berry skins. Plant Science 167: 247252.

25. Ferrara G, Mazzeo A, Matarrese AMS, Pacucci C, Punzi R, et al. (2015) Application of abscisic acid (S-ABA) and sucrose to improve colour anthocyanin content and antioxidant activity of cv. Crimson Seedless grape berries. Australian Journal of Grape Wine Research 21: 18-29.

26. Ju YL, Liu M, Zhao H, Meng JF, Fang YL (2016) Effect of exogenous abscisic acid and methyl jasmonate on anthocyanin composition, fatty acid, and volatile compounds of Cabernet Sauvignon (Vitis vinifira L) grape berries. Molecules 21(10): 1354 
27. Wang J, Wang S, Liu G, Edwards EJ, Duan W, et al. (2016) The synthesis and accumulation of resveratrol are associated with veraison and abscisic acid concentration in Beihong (Vitis vinifera $\mathrm{x}$ Vitis amurensis) berry skin. Front. Plant Sci. 7: 1605.

28. Peppi MC, Fidelibus MW, Dokoozlian N (2007) Timing and concentration of abscisic acid applications affect the quality of 'Crimson Seedless' grapes. International Journal of Fruit Science 7(4): 71-83.

29. Berli FJ, Fanzone M, Piccoli P, Bottini R (2011) Solar UV-B and ABA involved in phenol metabolismo of Vitisvinifera L. increasing biosynthesis of berry skin polyphenol. Journal of Agriculure Food Chemistry 59(9): 4874-4884.

30. Davies C, Böttcher C (2009) Chapter 9 Hormonal control of grape berry ripening. In: Roubelakis-Angelakis KA, Grapevine molecular physiology and biotechnology pp. 229-261.

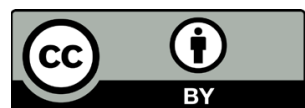

This work is licensed under Creative Commons Attribution 4.0 License DOI: 10.19080/JOJHA.2018.01.555554
31. Borges RS, Silva GA, Roberto SR, Assis AM, Yamamoto LY (2013) Phenolic compounds, favorable oxi-redox activity and juice color of 'Concord' grapevine clones. Science Horticulture 161: 188-192.

32. Ferrara G, Mazzeo A, Matarrese AMS, Pacucci C, Pacifico A, et al. (2013) Application of abscisic acid ( $S$-ABA) to 'Crimson Seedless' grape berries in a mediterranean climate: effects on color, chemical characteristics, metabolic profile, and $S$-ABA concentration. Journal of Plant Growth Regulation 32(3): 491-505.

33. Borges RS, Pudêncio SH, Roberto SR, Assis AM (2011) Sensorial evaluation of grape juice 'Isabel' blendings. Revista Brasileira de Fruticultura 33(special): 584-591.

34. Koyama R, Assis AM, Yamamoto LY, Prudêncio SH, Roberto SR (2015) Análise sensorial do suco integral de uva 'Isabel' submetida à aplicação de ácido abscísico. Revista Brasileira de Fruticultura 34(4): 893-901.

\section{Your next submission with Juniper Publishers will reach you the below assets}

- Quality Editorial service

- Swift Peer Review

- Reprints availability

- E-prints Service

- Manuscript Podcast for convenient understanding

- Global attainment for your research

- Manuscript accessibility in different formats

(Pdf, E-pub, Full Text, Audio)

- Unceasing customer service

Track the below URL for one-step submission https://juniperpublishers.com/online-submission.php 